\title{
Working on the Train? The Role of Technical Progress and Trade in Explaining Wage Differentials in Italian Firms*
}

\author{
Paolo Manasse ${ }^{\dagger}$ Luca Stanca
}

June 2003

\begin{abstract}
This paper presents firm-level evidence on the dynamics of the relative demand for non-manual workers in Italian manufacturing during the 1990s. The analysis provides a number of interesting results. First, the rise within firms in the share of non manual workers in both employment and hours worked (within-firm skill upgrading) is the main determinant of the increase in the relative demand for skilled workers. By contrast, demand changes associated to trade have mitigated such a rise by shifting employment away from skill-intensive firms. Second, while the relative number of hours worked by skilled workers within firms has risen, the hourly wage premium has fallen. Third, within-firm skill upgrading is strongly and significantly related to investment in computers and R\&D. Fourth, we find that technical progress has raised the relative productivity of skilled workers (the skill-bias of technical progress is positive). Finally we show that the standard approach that measures annual, rather than hourly relative
\end{abstract}

${ }^{*}$ We thank ISTAT for kindly providing the data for this study. We are indebted to Silvia Prina for excellent research assistance. Giorgio Basevi and Paolo Epifani provided useful comments.

${ }^{\dagger}$ Corresponding author. Department of Economics, University of Bologna, Strada Maggiore 45, 40100, Bologna, Italy. Telephone: \#39 $512092613 . \quad$ E-mail: manasse@spbo.unibo.it

${ }^{\ddagger}$ University of Milan-Bicocca.Pza Ateneo Nuovo 1, 20100 Milano, Italy. Telephone: \#39 26449 8877. E-mail: luca.stanca@unimib.it 
wages, produces a downward bias in the estimate of the skill-bias of technical progress.

JEL Classification: F1, F16, J31, O3

Keywords: wage differentials, skill bias, technical progress, globalization.

\section{Introduction}

Once upon a time, before the era of portable computers and cellular phones, commuters on the Milan-Rome train route broadly fell into two categories: first class travellers, mainly business people and academics, usually spending their time reading the financial and general press, or taking naps (the latter); economy class travellers, mainly families, young people and tourists, often involved in animated conversations with fellow travellers, typically about soccer or politics. Nowadays, first-class travellers can be seen silently hunched over their laptops, or heard noisily talking business over their cellular phones. Most second-class travellers still chat their way to their destination, although now over cellular phones, and some watch DVD's on their lap-tops. Academics, now travelling in economy class, either read newspapers or work on their laptops (or take naps). ${ }^{1}$

This anecdotal evidence suggests three working hypotheses: 1 . technical progress in Italy, as in many other countries, has been skill-biased, that is, it has raised the relative productivity of more educated workers (first-class travellers presumably make a more productive use of personal computers) as well as the relative number of hours worked by skilled workers (first class travellers now work instead of relaxing); 2. relative wages in Italy have not (fully) adjusted to the change in relative productivity and hours (as a consequence, academics can lo longer afford to travel - and take naps - in first class); 3. possibly as a result, firms have considerably raised the proportion of non-manual workers in employment.

This paper explores these conjectures by investigating the dynamics of manual and non-manual employment and wages in Italian manufacturing during the 1990s. We present firm-level evidence on the sources and determinants of the increase in the demand for non-manual workers, based on a new data set, previously unavailable for research, that covers a large panel of

\footnotetext{
${ }^{1}$ We are grateful to Giorgio Basevi for this example.
} 
manufacturing firms between 1989 and 1995. The analysis provides a number of results supporting these conjectures.

First, Italian firms have substituted unskilled for skilled workers at a rate comparable to those experienced in other industrialized countries, with hightech firms playing a leading role in this process (within-firm skill upgrading is the main determinant of the shift in relative labor demand in the nineties). Second, the relative stability of annual wage differentials within firms hides an important composition effect: at firm level the relative number of hours worked by skilled workers has risen, whereas relative hourly wages have fallen. Thus substitution toward skills has occurred not only in terms of employment but also in terms of hours worked. By contrast, demand changes associated to trade have moved employment away from skill-intensive firms, contributing to moderate the change in relative factor prices: between-firm employment shifts have reduced the relative demand for skills. Third, within-firm skill upgrading, measured by changes in both relative employment and number of hours, is strongly and significantly related to investment in computers and R\&D. Fourth, we find that technical progress has significantly raised the relative productivity of skilled workers (we estimate a positive skill-bias of technical progress). Finally, we show that the conventional approach that measures annual, rather than hourly relative wages, produces a downward bias in the estimate of the skill-bias of technical progress. The reason is that changes in relative hours worked are incorrectly attributed to changes in factor prices rather than quantities.

The paper is structured as follows. Section 2 briefly discusses the theoretical background of the analysis and relates the present work to the literature. Section 3 provides a description of the data set and presents some stylized facts of wage and employment dynamics in Italy in the last decade. In section 4 we present a decomposition of the aggregate changes in the relative wage bill, employment and wages, into their respective within-firm and betweenfirm components. Section 5 takes a closer look at the behavior of wages, and shows the implications of disaggregating annual wages into the number of hours worked and hourly wages. In section 6 we present evidence from firm-level regressions to provide an interpretation of the observed wage and employment dynamics, and section 7 focuses on the bias of skill-biased technical change. Section 8 concludes with a discussion of the main results. 


\section{Technology, trade and wages}

In the last two decades labor markets in OECD countries have witnessed a significant change in the structure of employment and wages for skilled and unskilled workers. In the United States and the United Kingdom, both the share of non-manual employment and the wage differential between manual and non-manual workers have grown considerably since the early 1980s. ${ }^{2}$ In continental Europe, wage differentials have been stable, and most of the adjustment has taken place on the quantity side, with rising non-manual workers' employment rates and manual workers' unemployment rates. ${ }^{3}$ The conventional wisdom for Europe is that the lack of adjustment in relative wages is due to more rigid labor market institutions (minimum wages, hiring and firing costs, centralized bargaining and union power, etc.), with unemployment rates adjusting to the falling demand for unskilled workers.

A large body of literature has attempted to provide an interpretation of these developments, ${ }^{4}$ with most studies concentrating on the determinants of the relative demand for skilled labor. ${ }^{5}$ In particular, trade integration and technological change have been considered the main factors behind the rise in demand for skilled workers. ${ }^{6}$ The "technology" view argues that technical progress has been skill-biased: new production practices associated to the introduction of computers have increased the relative productivity of skilled workers. This has led to higher relative demand, and in turn to higher employment share and wage premia for skilled workers. Empirically, skillbiased technical change is consistent with increased employment shares of skilled labor within individual sectors (or firms/plants, depending on the

\footnotetext{
${ }^{2}$ See e.g. Katz and Murphy (1992)), Bound and Johnson (1992), Lawrence and Slaughter (1993), Berman, Bound, and Griliches (1994)) for the United States, and Haskel (1998), Haskel and Slaughter (2001b)) for the United Kingdom.

${ }^{3}$ See e.g. Freeman and Katz (1996), OECD (1997), Berman, Bound and Machin (1998), Machin and Van Reenen (1998), Card, Kramarz, and Lemieux (1998).

${ }^{4}$ For recent surveys of this literature see Haskel (2000) and Slaughter (1999).

${ }^{5}$ As for supply, Katz and Murphy (1992) argue that lower relative supply of skills could account only for a small part of the observed changes in relative wages in the United States between 1963 and 1987. See also Topel (1997) for an analysis of the supply-side determinants of wage inequality.

${ }^{6}$ Other expanations often proposed are outsorcing (see e.g. Haskel (1996), Feenstra and Hanson (1999)), and changes in institutional factors such as the decline of the influence of unions, collective bargaining, and lower minimum wages (see e.g. Gosling and Machin (1993) and Fortin and Lemieux (1997)).
} 
level of aggregation and the specific way new technologies are adopted). The "trade" view points to Stolper-Samuelson effects of increased exposure to international trade. ${ }^{7}$ According to advocates of this explanation, competition from developing countries has lowered the relative price of unskilled-intensive goods. As resources have shifted to sectors producing more profitable skillintensive products, the relative demand for manual workers has fallen. This argument thus "blames" the growth of trade in goods, services and factors in the past three decades (i.e. "globalization"). Empirically, the trade view is consistent with employment moving from skill-unintensive towards skillintensive sectors (firms or plants).

The broad consensus emerging from the early empirical literature, generally based on studies of industry data, is that, while international trade accounts for no more than $15-20 \%$ of the rise in wage differentials, the rest can be explained by skill-biased technical progress (see e.g. Bound and Johnson (1992) and Berman et al. (1994) for the United States, but also Berman et al. (1998) and Machin and Van Reenen (1998) for an international perspective). ${ }^{8}$ This conclusion is supported by two main findings. First, most of the aggregate skill upgrading is due to changes within industries, whereas the reallocation of employment between industries plays a smaller role. Second, within-industry skill upgrading is significantly related to a number of indicators of technological change.

This explanation has been recently challenged, both empirically and theoretically. At the empirical level, a number of studies based on firm- or plant-level data reach conclusions significantly different from those obtained on the basis of industry data. ${ }^{9}$ Bernard and Jensen (1997), for example, find that within-industry increases in the demand for skilled labor can be largely attributed to shifts in employment between plants of the same industry (see also Bernard and Jensen (1995)), with exporting plants playing a major role. ${ }^{10}$ Earlier studies, it is argued, have ignored important dynam-

\footnotetext{
${ }^{7}$ See Richardson (1995), Wood (1995) and Slaughter (1998) for recent surveys on the effects of trade on wage dynamics.

${ }^{8} \mathrm{~A}$ similar conclusion has been reached using both price (e.g. Leamer (1996), Feenstra and Hanson (1996)) and volume (e.g., Borjas, Freeman and Katz (1997)) data to capture the effect of trade on the labor market.

${ }^{9}$ Most plant- and firm-level analyses aim at assessing the links between exporting activity and productivity (see e.g. Bernard and Jensen (1999) and Bernard et al. (2000)) or the existence of learning effects associated with the exports status of firms (see e.g. Clarides, Lauch and Tybout (1998)).

${ }^{10}$ For a theoretical explanation of this evidence see Manasse and Turrini (2001).
} 
ics occurring at the level of individual firms and establishments, and thus have largely underestimated the role of demand and trade. At the theoretical level, trade theorists have argued that what matters for factor prices (in a two-sector two-factor Heckscher-Ohlin economy) is the sector in which technical progress occurs, rather than its factor bias (see e.g. Leamer (1994, 1998)). ${ }^{11}$

There are relatively few studies on the Italian case. Most of the existing evidence for Italy is based on industry-level data. Bella and Quintieri (2000) analyze a panel of manufacturing industries, and argue that trade competition has had a small impact on employment changes, whereas technological progress has played a major role. Faini et al. (1999) reach similar conclusions on the limited role of trade for labor market dynamics, using a panel of fourteen manufacturing sectors between 1985 and 1995. Among firm-level studies, Dell'Aringa and Lucifora (1994) look at a cross section of metal-mechanical firms to discuss the role of trade unions in affecting wage differentials. ${ }^{12}$ Casavola et al. (1996) consider a large panel of firms between 1986 and 1990, finding that technological change explains most of the increase in relative employment. More recently, Manasse et al. (2001) analyze a panel of metal-mechanical firms and find that skill-biased technical change is the main determinant of skill upgrading, raising wage inequality within skilled workers (i.e. between managers and clerks) more than between manual and non-manual workers. ${ }^{13}$

Against this background, our paper contributes to the literature in several respects: data, methodology and, we think, results. As to the first aspect, we exploit a new and much more comprehensive data set for Italy, filling an important gap for assessing the role of technology and trade for this country; as to methodology, we provide a general and consistent approach to

\footnotetext{
${ }^{11}$ Krugman (1995), however, shows that this criticism rests on the assumption of local technical change affecting a small open economy. See Haskel (2000) for an interpretation of this debate, and Haskel and Slaughter (2001a) for empirical evidence on the role of sector bias for the dynamics of wage differentials.

${ }^{12}$ Erickson and Ichino (1995) and Dell'Aringa and Lucifora (2000) discuss the role of labor market institutions in explaining a compressed wage structure in Italy. Ferragina and Quintieri (1998) examine the relationship between export activity, productivity and performance. See also Quintieri and Rosati (1995) for an investigation of inter-industry wage differentials.

${ }^{13}$ This study also finds that trade has dampened the effects of technology on the labor market, as employment has shifted towards unskilled-intensive firms (see also Faini et al. (1999)).
} 
firm-level between/within decompositions; moreover, we show how previous estimates of the role of technical progress may contain a "bias of the bias", by attributing changes in relative hours to factor prices rather than quantities.

\section{The data}

Our analysis is based on firm-level data for the Italian manufacturing sector. The data set is drawn from the Statistical Information System on Enterprises (SISSI), developed by the Italian Statistical Institute (ISTAT, Central Directorate of Statistics on Institutions and Enterprises), and it combines information from four sources: the System of Accounts of Firms (SCI) and the Survey on Technological Innovation of Industrial Enterprises (INN), both collected on a yearly basis; the monthly statistics on Foreign Trade Flows (COE), and the Archives of Active Firms (ASIA, SIRIO, NAI). ${ }^{14}$

The data set provides information on the profit and loss account (sales, output, costs and outlays, value added, labor costs, capital depreciation and allowances, interests on debts, taxes, profits, etc.), the asset and liabilities account (real assets, financial assets and liabilities, financial and commercial credits and debits, etc.), firms' employment and wages, fixed capital formation, R\&D and exports. Our sample consists of a balanced panel of 8441 manufacturing firms, covering about 22 per cent of total manufacturing employment, with annual observations from 1989 to 1995. Data on employment and wages are available separately for manual workers (trainees and production workers) and non-manual workers (clerks and executives). ${ }^{15}$ The majority of firms in the sample (63\%) falls into the category of "medium" firms (between 25 and 100 employees), while 23\% are "large" (more than 100 employees) and the remaining $14 \%$ are "small" (below 25 employees). As for the geographic distribution, $80 \%$ of the firms in the sample are located in Northern Italy, $15.5 \%$ in Central Italy and the remaining $4.5 \%$ in the South. ${ }^{16}$

Table 1 provides a preliminary description of the data, reporting sample

\footnotetext{
${ }^{14}$ See Sorce and Fazio (1999) and Corsini, Di Francescantonio and Monducci (1998) for a more detailed description of the construction of the data set.

${ }^{15}$ Wages include salaries, social contributions paid by the firm, and contributions paid by the firm to the severance-payment fund (TFR).

${ }^{16}$ The three geographic areas are defined as follows. North: Piemonte, Valle D'Aosta, Lombardia, Alto Adige, Veneto, Friuli Venezia Giulia, Liguria, Emilia Romagna. Center: Toscana, Umbria, Lazio, Marche, Abruzzo, Molise. South: Campania, Basilicata, Puglia, Calabria, Sicilia, Sardegna.
} 
and (appropriately defined) sub-sample averages for a number of wage and employment indicators. Column 1 shows the share of non-manual workers in the wage bill $\left(\frac{W B_{n}}{W B}\right)$, while columns 2 and 3 display its components: the ratio of the wage rate of non-manual workers over the average wage $\left(\frac{W_{n}}{W}\right.$, henceforth "skill premium"), and the share of non-manual workers in employment $\left(\frac{E_{n}}{E}\right.$, henceforth "skill intensity"). In the period 1989-1995, on average, the share of non-manual workers in the wage bill was 43.3 per cent, the skill premium 135.9 per cent, and skill intensity 31.8 per cent. Table 1 also reports, in columns 4 and 5 , the average annual wage rate of non-manual and average workers ( $W_{n}=68.2$ and $W=50.2$ millions Italian lira, respectively); and, in columns 6 and 7, the number of non-manual and total employees in the sample $\left(E_{n}=43.3\right.$ and $E=136$ thousands, respectively).

Between 1989 and 1995 the share of non-manual workers in the wage bill rose by 3.5 percentage points (0.58 per cent a year, on average). This reflected a significant increase in skill intensity (2.4 per cent), with a relatively modest 0.8 per cent rise in the skill premium. Hence, relative wages in our sample conform to the "sticky" pattern found in other studies for earlier periods (e.g. Erickson, Ichino (1995)). The rise in skill-intensity, in turn, reflected an absolute increase of average non-manual employment (from 41.6 to 43.4 thousands) despite the contraction, from 137.8 to 133.2 thousands, of total employment (note that this implies that manual employment fell by 6.4 thousand units in our sample of firms).

The following blocks in Table 1 document the significant heterogeneity of firms in the sample as far as wages and employment are concerned. Grouping firms according to their size, larger firms pay substantially higher nominal wages than small and medium firms. Skill premia are highest in mediumsize firms (134.7 per cent) and lowest in small firms (128.5 per cent), while the wage bill share and skill intensity are increasing in size. Considering a classification based on the geographic distribution, firms located in the South are on average smaller (119.5 employees) and pay substantially lower wages than those in the rest of the country. Also, they appear to pay higher skill premia $(140.2 \%)$ than those in the rest of the country, although they are characterized by lower wage bill shares (36\%) and skill intensity $(25.7 \%)$.

Next, we consider two further classifications, according to their export activity and computer intensity. "High-export" ("low-export") firms are defined as those whose share of exports in total sales is above (below) the 
median. ${ }^{17}$ Similarly, "high-technology" ("low-technology") firms are defined as those whose share of computer stock over total capital stock is above (below) the median ${ }^{18}$. "High" and "low" exporters pay similar wages and have similar wage bill shares and skill intensity (despite the former being larger). "Technology-intensive" firms (henceforth "high-tech") employ a substantially higher proportion of skilled workers (35.4\% against $27.2 \%$ ). Despite paying higher salaries for both types of workers, the wage differentials are surprisingly lower in high-techs. The share of skilled worker in the wage bill is about 10 percentage points higher than low-tech firms.

Table 2 groups high/low-tech firms and high/low-export firms by size, since some of the features previously observed may be simply due to differences in scale. The figures suggest that the features of high-tech firms do not depend on their size: high-tech firms are more skill-intensive, pay lower premia, and have higher non-manual wage bill share than low-tech firms in all size groups. On the other hand, the similarities between high- and lowexporters in the total sample turn out to be a fallacy of composition: small and medium high-exporters are more skill intensive and pay lower skill premia than low-exporters of the same size, while the converse is true for large high-exporters.

\section{Firm-Level Decompositions}

In this section we present firm-level decompositions in order to provide an interpretation of the aggregate annual wage and employment changes described above. We decompose the change in the relative wage bill into the respective contributions of employment skill-intensity and wage skill-premium. Each of these is further disaggregated into a between and a within component. The former reflects reallocations of employment and wages that occur between different firms, and presumably reflect demand shifts; the latter identifies changes in the employment and wage structure that occur within individual firms, and possibly reflect technical change. We depart here from the literature in an important aspect: instead of focusing on the decompositions for the relative wage bill and employment intensity taken in isolation (see e.g. Berman et al., (1994), Bernard and Jensen (1997), Berman et al. (1998), Machin and Van Reenen (1998)) we proceed by nesting the wage bill

\footnotetext{
${ }^{17}$ Due to data limitations, the ratio of exports to total sales is only available for 1989 .

${ }^{18}$ Thus this classification is based firms' inputs, rather than on their output.
} 
with employment and wage decompositions. Unlike the standard approach, our methodology allows us to identify the respective contributions of annual wages and employment to the change in the wage bill share. Moreover, our approach provides explicit information on the changes of relative wages (see also Manasse et al., 2001).

Let the firms in the sample be indexed by superscript $i=1, \ldots, I$, and denote manual and non-manual workers with subscripts $m$ and $n$, respectively (so that $E_{n}^{i}$ and $W_{n}^{i}$ denote non-manual employment and wage in firm $i$ ). Firm $i$ employs $E^{i}=E_{n}^{i}+E_{m}^{i}$ workers. Total employment is $E=\sum_{i} E^{i}$, and total non-manual employment is $E_{n}=\sum_{i} E_{n}^{i}$. The average wage at the firm is defined as $W^{i}=\frac{W_{n}^{i} E_{n}^{i}+W_{m}^{i} E_{m}^{i}}{E_{n}^{i}+E_{m}^{i}}=\frac{W B^{i}}{E^{i}}$ and the non-manual wage at the firm is defined as $W_{n}^{i}=\frac{W_{n}^{i} E_{n}^{i}}{E_{n}^{i}}=\frac{W B_{n}^{i}}{E_{n}^{i}}$. Finally, let $W=\frac{\sum_{i} W^{i} E^{i}}{\sum_{i} E^{i}}=\frac{W B}{E}$ and $W_{n}=\frac{\sum_{i} W_{n}^{i} E_{n}^{i}}{\sum_{i} E_{n}^{i}}=\frac{W B_{n}}{E_{n}}$ denote the (sample-wide) average mean wage and mean non-manual wage, respectively.

The change in the share of non-manual workers in the wage bill can be decomposed as follows:

$$
\Delta\left(\frac{W B_{n}}{W B}\right)=\Delta \sum_{i}^{I}\left(\frac{W_{n}^{i}}{W} \frac{E_{n}^{i}}{E}\right)=\sum_{i=1}^{I}\left[\Delta\left(\frac{W_{n}^{i}}{W}\right) \overline{\left(\frac{E_{n}^{i}}{E}\right)}+\Delta\left(\frac{E_{n}^{i}}{E}\right) \overline{\left(\frac{W_{n}^{i}}{W}\right)}\right]
$$

where $\Delta$ denotes time difference and the upper bar denotes an average over time. The first term in the square brackets in (1) is the sum of changes in wage premia, weighted by the time-average share of non-manuals in employment (Wtot). The second term is the sum of changes in skill intensities, weighted by the corresponding time-average of wage premia (Etot).

Consider first the employment component (Etot). This may rise for two reasons: either individual firms have, on average, become more skill-intensive (within effect), or employment has shifted towards firms that are relatively intensive of skilled workers (between effect). Similarly, for the wage component (Wtot) higher wage premia may be due either to the fact that individual firms have, on average, paid higher skill premia (within effect), or to the fact that average wages have grown more rapidly in firms paying relatively higher premia (between effect). In order to disentangle these different sources, we decompose the two terms in equation (1) into their respective between and within components. 
The (weighted) employment component can be written as follows:

$$
\sum_{i}^{I} \Delta\left(\frac{E_{n}^{i}}{E}\right) \overline{\left(\frac{W_{n}^{i}}{W}\right)}=\sum_{\text {Etot }}^{I}\left[\begin{array}{c}
\Delta P_{\text {Ewit }}^{i} \overline{S^{i}}+\underset{E b e t}{\Delta S_{n}^{i}} \overline{P_{n}^{i}}
\end{array}\right] \overline{\left(\frac{W_{n}^{i}}{W}\right)}
$$

where $P_{n}^{i}=\frac{E_{n}^{i}}{E^{i}}$ is the proportion of skilled workers in firm $i$ 's employment, and $S^{i}=\frac{E^{i}}{E}$ is the share of firm $i$ in total employment. The first term in square brackets represents the change in the non-manual employment share that can be attributed to changes in firms' factor proportions, $P_{n}^{i}$, keeping constant their relative size, $S^{i}$. This reflects shifts in factor intensity within firms (henceforth denoted with Ewit): if positive, it suggests that on average firms have substituted unskilled with skilled workers. The second term gives the part of the total change that can be attributed to the change in firms' employment share or relative size, $S^{i}$, keeping each firm's factor proportions constant. This reflects movements of employment between firms (and is denoted by Ebet): if positive, it suggests that employment has shifted, on average, towards skill-intensive firms.

Similarly, the (weighted) wage component can be disaggregated as follows:

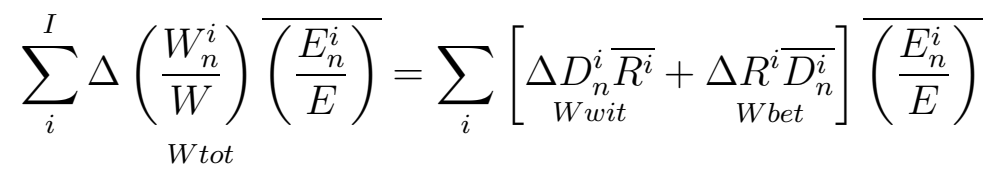

where $D_{n}^{i}=\frac{W_{n}^{i}}{W^{i}}$ is the wage differential paid by firm $i$, and $R^{i}=\frac{W^{i}}{W}$ is the relative wage paid by firm $i$ as a ratio of the average (sample-wide) wage rate. The first term in square brackets is the part that can be attributed to changes in firms' wage differentials, $D_{n}^{i}$, keeping constant their relative wages, $R^{i}$. This is the wage-within component (Wwit): if positive, it suggests that on average firms have raised skill premia. The second term accounts for the changes in firms' relative wage rates, keeping their wage premia constant. This is the between component (Wbet): it is positive if, on average, wages have risen faster in firms that pay higher premia.

Summing up, within-firm movements presumably reflect factor-specific shocks, such as changes in the relative factor productivity and/or wage premia, due to skill-biased technical progress. Between movements presumably reflect firm and sector-specific shocks, such as changes in domestic and for- 
eign demand affecting market shares and/or average wage rates. ${ }^{19}$

Table 3 presents the results of the decompositions in equations (1-3): the average annual change of the share of non manual workers in the wage bill (WBtot), and the contributions of the change in skill intensity (Etot) and the change in skill premium (Wtot), split further into their respective between and within contributions (Ebet, Ewit, Wbet, Wwit). The first row displays the results for the overall sample of firms. ${ }^{20}$ Between 1989 and 1995 the share of non manual workers in the wage bill rises on average by 0.58 per cent a year. This is largely accounted for by the skill intensity component $($ Etot $=0.51$ per cent $)$, with a smaller contribution of the wage premium component $(W t o t=0.07$ per cent). Interestingly, the rise in the proportion of skilled workers in employment is due to substantial within-firm substitution of unskilled with skilled labor (Ewit $=0.63$ per cent a year), whereas the between component is negative (Ebet $=-0.12$ per cent), partially offsetting the effect of the within component.

This means that, on average, employment has moved towards unskilledintensive firms, thus moderating the rise in the proportion of skilled workers in employment. ${ }^{21}$ Looking at the wage components, most of the (very small) total change can be attributed to the between effect (Wbet $=0.06$ per cent): on average wages have risen somewhat faster in firms paying higher skill premia.

Rows 2 and 3 of table 3 divide the 1989-95 sample into two four-year subperiods (1989-92 and 1992-95). The results indicate that, for both relative employment and wages, changes were much larger in the first sub-period: the share of non-manual workers in the wage bill rose at an average annual rate of 1 per cent between 1989 and 1992, as opposed to just 0.17 per cent between 1992 and 1995. It is interesting to observe that this deceleration is largely explained by the employment component. In particular, the relative expansion of employment in unskilled-intensive firms (the negative Ebet) occurs only in the second sub-period, 1992-95, a period of booming manufacturing exports, particularly for low skill intensive firms, spurred by a rapidly depreciating real exchange rate (see Manasse et al. (2002)). In the same

\footnotetext{
${ }^{19}$ Clearly, demand and trade may indirectly affect within-firm changes through their impact on factor prices (see below).

${ }^{20}$ Note that the lower number of observations (compared to table 1 ) is due to the presence of firms employing only manual workers.

${ }^{21}$ This result confirms the findings in Manasse et al. (2001) for the metal-mechanical sector. See also Faini et al. (1999) for similar results based on industry data for Italy.
} 
period skill-upgrading (the positive Ewit) also slows down.

The next blocks in table 3 show the contributions of individual subsamples of firms to the overall decomposition. Looking at the classification of firms by their computer-intensity, two interesting features appear from the table. First, high-tech firms account for a large share of the rise of skill intensity within firm (Ewit about 0.40 per cent as opposed to 0.24 per cent for low-tech firms). This finding is consistent with the hypothesis that new technologies (computers) and skills are complement, so that technical change has indeed been skilled-biased. Second, high-tech firms also entirely account for the negative employment between component, Ebet. Thus high tech firms, the most active in raising their skill intensity, have lost market shares during this period. Looking at the classification of firms by their export activity, we observe an important result: high-export firms account entirely for the negative employment between component. The last two findings suggest that the Italian specialization pattern in international trade is shifting employment towards unskilled-intensive goods and away from computer-intensive firms. ${ }^{22}$ Notice also that, when we classify firms jointly for computer-intensity and export-activity, skill-upgrading (Ewit) occurs equally for all high-tech firms (irrespective of being high or low exporters), whereas the loss of employment share (Ebet) is more evident among high-tech exporters.

\section{Hours and hourly wages}

In this section we examine our "working on the train" conjecture that technical progress affects on the relative number of hours worked by non manual workers. The point here is that considering annual rather than hourly wages, that is lumping together the number of hours with the hourly wage rate, as generally done in the literature, is potentially misleading. When hours change, this erroneously shows up in factor prices (annual wages) rather than in factor quantities (total hours employed). Thus the previous decompositions may be misleading, and estimates of the skill-bias of technical progress (see below) may be biased.

We obtain the average number of hours worked per employee in firm $i\left(h^{i}\right)$

\footnotetext{
${ }^{22}$ It should be noted that the negative employment between component is largely attributable to large firms (-0.13 per cent). Within these firms, high-exporters are indeed less skill intensive than low-exporters (relative skilled employment is 33.5 and 36.4 , respectively).
} 
by dividing the number of hours worked in firm $i\left(H^{i}\right)$ by the number of its employees $\left(E^{i}\right): h^{i}=\frac{H^{i}}{E^{i}}$. The hourly average wage at the firm is then defined as the ratio between the annual wage rate and the average number of hours per employee: $\omega^{i}=\frac{W^{i}}{h^{i}}$. The average non-manual hours and hourly wage rates at firm $i, h_{n}^{i}, \omega_{n}^{i}$ are calculated similarly.

Table 4 shows sample and sub-sample means across firms for average worker's and non-manual worker's hours ( $h$ and $h_{n}$, respectively), hourly wage rates $\left(\omega\right.$ and $\left.\omega_{n}\right)$, and the corresponding "hourly" skill intensity $\left(\frac{h_{n}}{h}\right)$ and wage premium $\left(\frac{\omega_{n}}{\omega}\right)$. In the entire sample, non manual employees work longer hours per year (1720.6 vs. 1665.2), and earn higher hourly wages than average workers (39.6 vs. 30.1 thousand lire per hour, corresponding to Euro 20.45 and 15.6 respectively). The average hourly skill premium and hourly intensity are thus 131.5 and 103.3 per cent, respectively. Looking back at Table 1, we see that in the total wage premium of 135,9 (first row, second column), only 131,5 (Table 4 ) is the actual price differential, the rest simply reflecting differences in hours. Looking at changes between 1989 and 1995, the hourly wage premium rises by 1.2 percentage points, while hourly skill intensity rises until 1993 and then falls back to just below the initial level. Comparing this with the change in relative annual wages $\left(\frac{W_{n}}{W}\right)$, Table 1 second column, we see that the modest rise in relative annual wages is (more than) entirely due to the rise in the hourly premium $\left(\frac{\omega_{n}}{\omega}\right)$. The hourly wage premium is smaller in high-tech and high-export firms, while hourly skill intensity is relatively more uniform across firms.

Proceeding as before, we aim at separating the (between) changes resulting from compositional effects from those occurring at firm level (within). Thus we calculate between/within decompositions for the three components of the relative wage bill (see Appendix for details), employment $(E)$, hours worked $(H)$ and hourly wages $(H W)$ :

$$
\Delta\left(\frac{W B_{n}}{W B}\right)=(\text { Ewit }+ \text { Ebet })+(\text { Hwit }+ \text { Hbet })+(H W w i t+H W b e t)
$$

The results, presented in Table 5, are revealing, particularly when compared with those reported in Table 3 . The apparent stability of annual wage premia within firms ( $W$ wit $=0.01$ in table 3 ), hides the offsetting contributions of hours and hourly wages: relative non-manual hours have risen at the annual rate of $H w i t=0.19$, while, given lack of adjustment in salaries, the within firm hourly premium $H W$ wit has fallen at the same rate. Given that the relative price of an hour of skilled labor has actually declined, firms have 
substituted manual with non-manual workers not only in terms of employment levels (on the extensive margin), at the annual rate of Ewit $=0.63$, but also in terms of hours (on the intensive margin), at the annual rate of Hwit $=0.19$. The latter phenomenon is simply obscured when the standard definition of annual wages is used. Relative total non-manual hours have therefore risen approximately at the annual rate of $0.63+0.19=0.82$ which is about one third above the estimate in Table 3 . We now turn to the interpretation of these decompositions.

\section{$6 \quad$ Interpreting the decompositions}

So far we have interpreted the within and between components as reflecting technology and demand shocks, respectively. This interpretation, however, is not warranted: within-firm changes may also be due to demand shocks. Suppose, for example, that the domestic relative price of unskilled-intensive ("traditional") goods rises, due to a change in preferences or to trade liberalization. ${ }^{23}$ As new firms enter the "traditional" sector, the share of unskilled workers in employment rises (between effect). The resulting excess demand for unskilled workers lowers the wage premium, and induces firms to substitute manual with non-manual workers (a positive employment within effect). In this case, a demand shock (between firms) indirectly causes a (within firm) change in factor proportions. Attributing the latter to technology would be incorrect, and it would result in overestimating the role of technology (and underestimating that of demand or trade).

In this section we therefore examine whether it is correct to interpret within and between components as reflecting technology and demand, respectively. We regress the between and within changes of wages (both annual and hourly), employment and hours, on variables that proxy for firm-level demand and technology shocks. If the standard interpretation is correct, within-firm changes should be significantly related to technology but not to demand variables, while the converse should be true for between changes.

We use the rate of growth of total sales as an indicator of the change in demand for a firm's output, and consider two alternative indicators of technological change at firm-level: the ratio of investment in computers over total investment, and the ratio of research and development expenditures over

\footnotetext{
${ }^{23}$ We thank Paolo Epifani for raising this point.
} 
total sales ${ }^{24}$. All the regressions include size, region, and industry dummies to allow for different firm and industry characteristics. The general specification is therefore:

$$
\Delta C_{d}^{i}=\alpha+\beta_{1} \Delta l S^{i}+\beta_{2} I C I^{i}+\beta_{3} R D S^{i}+\sum_{j} \gamma_{j} D U M_{j}
$$

where $\Delta C_{d}^{i}$ indicates firm $i^{\prime}$ s contribution to the overall change in the relative wage bill, employment and (annual and hourly) wage $(\Delta C=W B$, $E, W, H W, H)$, and the subscript $d=$ bet, wit denotes between and within components, respectively; $\Delta l S$ is the growth rate of total sales, $I C I$ is the ratio of the firm's investment in computers over total investment, $R D S$ is the ratio of Research and Development expenditures over total sales, and $D U M$ represents a set of industry, size and geographic dummies.

The results of OLS estimation of equation (5), presented in table 6, are quite revealing ${ }^{25}$. The growth rate of sales has a positive and highly significant coefficient in all between regressions (with the exception of the hourly wage equation): demand shocks are positively related to between-firm changes in both employment and annual wages, but not to within changes (with the exception of hours, Hwit, and hourly wages, HWwit). Looking at the technology indicators, the computer share of investment $I C I$ is positive and significant in the wage bill and employment within equations, while negative but never significant in the between equations. The research and development indicator $R D S$ is positive but only marginally significant in the wage bill and employment within equations. Interestingly, it is positive and strongly significant in the equation for the within firm relative number of hours, Hwit. The results for hourly wages are less clear-cut: the within component is significantly related to both the growth of sales (positively) and the R\&D indicator (negatively); the between component is not significantly affected by either demand or technology indicators.

Overall, the evidence suggests that between-firm changes for all the indicators examined are positively and significantly related to changes in demand. In addition, there is a positive and significant relationship between technical change, as measured by investment in computers and R\&D intensity, and

\footnotetext{
${ }^{24}$ The R\&D variable also contains expenditures for patents, concessions, and copyrights.

${ }^{25}$ The lower number of observations (from 8203 in the decompositions to 7377 in the regressions) is largely due to data limitations on the technology indicators: only 8005 and 7830 observations, respectively, are available for the computer intensity and research and development indicators.
} 
within-firm skill upgrading both on the extensive margin (number of employees) and the intensive margin (number of hours worked per employee).

\section{The biased bias of technical change}

In the previous sections we found that main determinant of the rise of the non-manual employment and wage bill shares is firms substituting nonmanual for manual workers. In this section, we use a cost function framework to measure effect of technical change on the relative productivity of non-manual workers (the so called skill-bias of technical change). We find a positive and significant skill-bias. Also, we show that the common practice of defining relative wages in terms of annual, rather than hourly, salaries, produces a downward bias in the estimates of the skill-bias as well as of the elasticity of factor substitution.

In order to isolate the effect of technical progress on factor shares, one needs to control for changes in factor prices and capital intensity: the rise in the share of skilled workers within firms may be simply due to a fall in their relative factor prices or to capital deepening when skills and capital are complement. Following the literature (see Binswanger, 1974) we therefore define technical progress as a reduction in unit cost (an inward shift of the unit-isoquant) at constant factor prices and capital intensity. Technical progress is neutral if, despite lower unit costs, firms on average do not change factor proportions, at given factor prices and capital intensity. However, if they increase on average the proportion of skilled workers in employment (when they pick a new tangency point on an lower isocost line of the same slope), then technical progress raises the relative productivity of non-manual workers and is defined skill biased.

Empirically, we implement this approach following Berman et al. (1994), and Brown and Christensen (1981). An equation for the wage bill share can be derived from a translog cost function with quasi-fixed factors of production. Assume that firms choose variable factors, manual and non manual labor, in order to minimize costs, subject to an output constraint. Production requires (manual and non-manual) labor and capital, which is fixed in the short run. The cost function has the translog functional form, and returns to scale are constant. Under these assumptions the change in the share 
of non-manuals in the wage bill can be written as follows:

$$
\Delta\left(\frac{W B_{n}^{i}}{W B^{i}}\right)=\alpha+\beta \Delta \ln \left(\frac{w_{n}^{i}}{w_{m}^{i}}\right)+\gamma \Delta \ln \left(\frac{K^{i}}{Y^{i}}\right)+\varepsilon^{i}
$$

where $K_{i}$ and $Y_{i}$ represent capital and value added, respectively (the actual specification also includes a set of industry, size and geographic dummies, as in (5)). Note that the intercept $\alpha$ measures of the average bias in technical change, and the residual $\varepsilon^{i}$ provides an estimate of the firm-specific bias. If the slope coefficient $\beta$ is positive (negative) a change in relative price of a factor raises (lowers) its cost share, implying that the elasticity of substitution between inputs is below (above) unity $\left(\sigma=\frac{-\beta+s_{n}\left(1-s_{n}\right)}{s_{n}\left(1-s_{n}\right)}\right.$, where $\left.s_{n}=\frac{W B_{n}}{W B}\right)$. A positive (negative) estimate for $\gamma$ implies that capital is complement (substitute) to non-manual labor, since it raises (lowers) its wage bill share at constant factor prices. In the following we present results obtained estimating the above equation using either annual or hourly wages $(w=W, \omega)$ as explanatory variable.

Table 7 reports OLS estimation results using annual wages. We estimate equation (6) in its basic version, and subsequently add, either individually or jointly, the two indicators of technological change described above (computers as a share of total investment and R\&D over sales). Starting from the basic specification, we see that the constant is positive and significant: the increase in the relative productivity of non manual workers (the bias of technical progress) occurs at an annual rate of 0.48 and thus raises the wage bill share of skilled workers by almost half of a percentage point per year. The change in relative wages have a positive and statistically significant coefficient, implying an elasticity of substitution between labor inputs of $\sigma=0.49$. The coefficient of the capital-value added ratio is also positive and significant, indicating complementarity between capital and skilled labor. Capital deepening has thus contributed to skill upgrading. When we add to the basic model technology indicators individually (equations 2-3) or jointly (equation 4 ), both the computer share of total investment and R\&D expenditures as a fraction of sales have positive and highly statistically significant coefficients. The estimate of the skill bias falls slightly (to 0.44) when explicit proxies of technical progress are included in the equation, while the estimated elasticity of substitution is remarkably stable across different specifications. ${ }^{26}$

\footnotetext{
${ }^{26}$ The results are also robusts to the use of beginning-of-period levels for the technology indicators.
} 
Next we re-estimate the previous equation with hourly wages on the right hand side, and obtain the results shown of Table 8. Compared with those in Table 7, the parameters for capital deepening and the computer share in investment are virtually unchanged, while the estimates for the ratio of $R \& D$ expenditures over sales are more precisely estimated and almost double in size. Moving to hourly wages has two more important consequences: the estimated skill-bias rises consistently in all specifications, respectively from $\alpha$ in the range $(0.48,0.44)$ to $\alpha^{\prime}$ in the range $(0.52-0.48)$. Similarly, the estimated elasticity of substitution rises from $\sigma=0.49$ to $\sigma^{\prime}=0.67$. The reason for the larger estimated skill bias is the following: technical progress raises, as we saw, the relative number of non-manual hours, but when wages are incorrectly measured (on an annual, rather than hourly basis), this effect is attributed to higher relative factor prices, rather than to the bias. As for the larger elasticity of substitution, note that in the second specification this elasticity effectively measures the change in total hours (employment plus average hours) induced by a change in relative factor prices, so that the estimated elasticity must also be larger As long as technical innovation and skilled hours are complement, previous estimates of the skill-bias (and of the elasticity of substitution), e.g. Berman et al., 1994, Berman et al., 1998, are therefore likely to be biased downwards.

Summing up, our estimate suggests that skill-biased technological change has raised the relative productivity of non manual workers an annual rate of roughly half of a percentage point, and thus was the key determinant of the increase in the demand for non-manual workers in Italian manufacturing during the 1990s. We also found that in order to assess the role of technical progress on wage inequality and skill upgrading, it is important to disaggregate annual wage rates into the number of hours worked and their hourly price. The current practice in the literature fails to do so, and therefore erroneously attributes changes in hours to factor prices rather than quantities. This produces a downward bias in the estimated skill-bias of technical progress.

\section{Discussion and conclusions}

This paper has presented firm-level evidence on the dynamics of wage premia and relative employment and hours in Italian manufacturing in the nineties. We have exploited a brand new data set, previously unavailable for research, 
that covers a balanced panel of 8441 manufacturing firms between 1989 and 1995. The analysis has reached a number of interesting results on the effects of technology and trade on employment and wages in Italian manufacturing firms.

First, Italian firms have substituted unskilled for skilled workers at a rate comparable to those experienced in other industrialized countries, with hightech firms playing a leading role in this process (within-firm skill upgrading is the main determinant of the shift in relative labor demand in the nineties). This result is a new, and somewhat unexpected, result, given that most studies on European economies find significant effect of technical progress at sector level only after 1995 (e.g. Daveri, 2000).

By contrast, demand changes associated to trade have moved employment away from skill-intensive firms, contributing to moderate the change in relative factor prices (between-firm employment shifts has reduced the relative demand for skills). This finding is consistent with results in Manasse et al (2002), and is probably due to the anomalous specialization pattern of Italian trade. During the nineties firms has become increasingly specialized in unskilled-intensive "traditional" goods (such as shoes, textiles, furniture etc., see Chiarlone, 2001).

Second, the relative stability of wage differentials within firms hides an important composition effect: the relative number of hours worked by skilled workers has risen whereas relative hourly wages have fallen. The narrowing of hourly skill premia in the face of technical progress may come unexpected, particularly to readers unfamiliar with the features of the Italian labor market. Yet it is well known the Italian centralized system of wage bargaining systematically fails to tailor wages to firms and workers productivity, with unions acting as a powerful instrument of wage equalization. For example, salaries in the South are equalized to salaries in the North, despite large productivity gaps, and this is generally regarded as an explanation of a rate of unemployment which is four times larger in the South than in the North. In addition, possibly as a result of this compression in relative hourly wages, Italy has been exporting college graduates and skilled workers ("the brain drain") at a rate that has no comparison in Europe (see Becker, Ichino and Peri (2002))

Third, within-firm skill upgrading, measured by changes in both relative employment and number of hours, is strongly and significantly related to investment in computers and R\&D).

Fourth, technical progress has raised the relative productivity of non 
manual-worker at an annual rate of half a percentage point, and therefore the skill bias has been a key determinant of the increase in the relative demand for non-manual workers in Italian manufacturing in the last decade.

Finally, the paper makes an important methodological point: in order to assess the role of technical progress on wage inequality and skill upgrading, it is essential to disaggregate hours worked from their price. Failing to do so, and attributing hours to factor prices rather than quantities, biases downward the estimates of the skill bias whenever technical progress and hours are complement.

Whether these results extend beyond the manufacturing sector is one of the questions to be investigated in further research. 


\section{$9 \quad$ Appendix}

This appendix provides some details on the derivation of the contributions of employment, hours worked and hourly wages to the wage bill presented in section 5:

$$
\begin{aligned}
& \Delta\left(\frac{W B_{n}}{W B}\right)=\Delta \sum_{i}^{I}\left(\frac{E_{n}^{i}}{E} \frac{W_{n}^{i}}{W}\right) \\
& =\sum_{i}^{I}\left[\Delta\left(\frac{E_{n}^{i}}{E}\right) \overline{\left(\frac{W_{n}^{i}}{W}\right)}+\Delta\left(\frac{W_{n}^{i}}{W}\right) \overline{\left(\frac{E_{n}^{i}}{E}\right)}\right]= \\
& =\sum_{i}^{I}\left[\begin{array}{c}
\Delta\left(\frac{E_{n}^{i}}{E}\right) \overline{\left(\frac{W_{n}^{i}}{W}\right)}+\Delta\left(\frac{h_{n}^{i}}{h}\right) \overline{\left(\frac{\omega_{n}^{i}}{\omega}\right)} \overline{\left(\frac{E_{n}^{i}}{E}\right)}+ \\
\Delta\left(\frac{\omega_{n}^{i}}{\omega}\right) \overline{\left(\frac{h_{n}^{i}}{h}\right)} \overline{\left(\frac{E_{n}^{i}}{E}\right)}
\end{array}\right]= \\
& =\sum_{i}^{I}\left[\begin{array}{c}
\Delta\left(\frac{E_{n}^{i}}{E^{i}}\right) \overline{\left(\frac{W_{n}^{i}}{W}\right)}+\Delta\left(\frac{E^{i}}{E}\right) \overline{\left(\frac{W_{n}^{i}}{W}\right)}+ \\
\Delta\left(\frac{h_{n}^{i}}{h^{i}}\right) \overline{\left(\frac{E w i t}{\omega}\right)} \overline{\left(\frac{\omega_{n}^{i}}{E}\right)}+\Delta\left(\frac{h^{i}}{h}\right) \overline{\left(\frac{\omega_{n}^{i}}{\omega}\right)} \overline{\left(\frac{E_{n}^{i}}{E}\right)}+ \\
\Delta\left(\frac{\omega_{n}^{i}}{\omega^{i}}\right) \overline{\left(\frac{h_{n}^{i}}{h}\right)} \overline{\left(\frac{E_{n}^{i}}{E}\right)}+\Delta\left(\frac{\omega^{i}}{\omega}\right) \overline{\left(\frac{h_{n}^{i}}{h}\right)} \overline{\left(\frac{E_{n}^{i}}{E}\right)} \\
H W w i t
\end{array}\right]
\end{aligned}
$$

The first, second and third line above correspond to the first, second and third term of equation (4) in the text 


\section{References}

Becker, Sascha O., Andrea Ichino, and Giovanni Peri (2003) 'How large is the 'brain drain' from italy?' Giornale degli Economisti e Annali di Economia

Bella, Mariano, and Beniamino Quintieri (2000) 'The effect of trade on employment and wages in italian industry.' Labour 14, 291-309

Berman, Eli, John Bound, and Stephen Machin (1998) 'Implications of skillbiased technological change: International evidence.' Quarterly Journal of Economics pp. 1245-1280

Berman, Eli, John Bound, and Zvi Griliches (1994) 'Changes in the demand for skilled labor within u.s. manufacturing: Evidence from the annual survey of manufactures.' Quarterly Journal of Economics pp. 367-397

Bernard, Andrew B., and Bradford J. Jensen (1995) 'Exporters, jobs and wages in u.s. manufacturing: 1976-1987.' Brookings Papers on Economic Activity: Microeconomics pp. 67-119

_ (1997) 'Exporters, skill upgrading and the wage gap.' Journal of International Economics 42, 3-31

_ (1999) 'Exceptional exporter performance: Cause, effect, or both?' Journal of International Economics 47, 1-25

Binswanger, Hans P. (1974) 'The measurement of technical change biases with many factors of production.' American Economic Review pp. 964976

Black, Sandra E., and Lisa M. Lynch (2000) 'What's driving the new economy: The benefits of workplace innovation.' Technical Report 7479, NBER Working Paper

Borjas, G. J. (1980) 'The relationship between wages and weekly hours of work: The role of division bias.' Journal of Human Resources 15, 409423 
Borjas, George J., Richard Freeman, and Lawrence Katz (1992) 'On the labor-market effects of immigration and trade.' In 'Immigration and the Workforce' (Chicago: University of Chicago Press) chapter aa, pp. 21344

Bound, John, and George Johnson (1992) 'Changes in the structure of waes during the 1980s: An evaluation of alternative explanations.' American Economic Review 82, 371-92

Brown, Randall S., and Laurits R. Christensen (1981) 'Estimating elasticities of substitution in a model of partial static equilibrium: An application to u.s. agriculture, 1947 to 1974.' In Modeling and Measuring Natural Resource Substitution, ed. Ernst R. Berndt and Barry C. Field (Cambridge, MA: MIT Press) pp. 209-29

Card, D., F. Kramarz, and T. Lemieux (1998) 'Changes in the relative structure of wages and employment: A comparison of canada, france and the united states.' Technical Report 2008, CEPR Working Paper

Casavola, Paola, Andrea Gavosto, and Paolo Sestito (1996) 'Technical progress and wage dispersion in italy: Evidence from firms' data.' $A n$ nales d'Economie et Statistique 0, 387-412

Clerides, S., S. Lauch, and J. Tybout (1998) 'Is learning by exporting important?' Quarterly Journal of Economics 454, 903-47

Corsini, V., T. Di Francescantonio, and R. Monducci (1998) 'Costruzione di base dati per l'analisi della struttura e della dinamica del sistema di imprese.' Technical Report, ISTAT, Direzione Centrale delle Statistiche su Istituzioni e Imprese

Daveri, Francesco, and Guido Tabellini (1997) 'Unemployment, growth and taxation in industrial countries.' Technical Report 122, IGIER Working Paper

Dell'Aringa, Carlo, and Claudio Lucifora (1994) 'Collective bargaining and relative earnings in italy.' European Journal of Political Economy $10,727-47$

(2000) 'Inside the black box: Labour market institutions, wage formation and unemployment in italy.' Rivista di Politica Economica 90, 13-55 
Erickson, Christopher, and Andrea Ichino (1995) 'Wage differentials in italy: Market forces, institutions and inflation.' In Differences and Changes in the Wage Structure, ed. R. Freeman and L. Katz (Chicago: University of Chicago Press) pp. 268-305

Faini, Riccardo, Anna Falzoni, Marzio Galeotti, Rodolfo Helg, and Alessandro Turrini (1999) 'Importing jobs and exporting firms? on the wage and employment implications of italian trade and foreign direct investment flows.' Giornale degli Economisti e Annali di Economia

Feenstra, R., and G. Hanson (1999) 'The impact of oustorcing and hightechnology capital on wages: Estimates for the u.s., 1972-1990.' Quarterly Journal of Economics 114, 907-40

Ferragina, A. M., and B. Quintieri (2000) 'Caratteristiche delle imprese esportatrici italiane. un'analisi su dati mediocredito e federmeccanica.' Technical Report 14, ICE Working Paper

Fortin, N., and T. Lemieux (1997) 'Institutional changes and rising wage inequality: Is there a linkage?' Journal of Economic Perspectives

Freeman, Richard, and Lawrence Katz (1996) Differences and Changes in Wage Structure (Chicago: University of Chicago Press)

Gosling, Amanda, and Stephen Machin (1993) 'Trade unions and the dispersion of earnings in british establishments, 1980-90.' Oxford Bulletin of Economics and Statistics 57, 167-184

Haskel, J., and Y. Heden (1998) 'Computers and demand for skilled labour: Industry and establishment level panel evidence for the united kingdom.' Technical Report 1907, CEPR Discussion Paper

Haskel, Jonathan (1996) 'Small firms, contracting-out, computers and wage inequality: Evidence from UK manufacturing.' Technical Report 1490, CEPR Discussion Paper

(2000) 'Trade and labor approaches to wage inequality.' Review of International Economics 8, 397-408

Haskel, Jonathan, and Matthew Slaughter (2001a) 'Does the sector bias of skill-biased technological change explain changing skill premia?' European Economic Review p. forthcoming 
(2001b) 'Trade, technology, and UK wage inequality.' Economic Journal $110,163-87$

Katz, Lawrence F., and Kevin M. Murphy (1992) 'Changes in relative wages, 1963-1987: Supply and demand factors.' Quarterly Journal of Economics pp. 35-78

Krueger, A. (1993) 'How computers have changed the wage structure: Evidence from microdata, 1984-89.' Quarterly Journal of Economics 93, 3360

Krugman, Paul R. (1995) 'Technology, trade and factor prices.' Technical Report 5355, NBER working paper

Lawrence, Robert, and Matthew Slaughter (1993) 'International trade and american wages in the 1980s: Giant suching sound or small hiccup?' Brookings Papers on Economic Activity, Microeconomics 2, 161-211

Leamer, Edward (1996) 'Wage inequality from international competition and technological change: Theory and country experience.' American Economic Review May, 309-314

(1998) 'In search of stolper-samuelson effects on US wages.' In Exports, Imports, and the American Worker, ed. S. Collins (Washington D.C.: The Brookings Institution)

Machin, Stephen, and John VanReenen (1998) 'Technology and changes in skill structure: Evidence from seven OCED countries.' Quarterly Journal of Economics 113, 1215-44

Manasse, Paolo, and Alessandro Turrini (2001) 'Trade, wages, and superstars.' Journal of International Economics 54, 97-117

Manasse, Paolo, Luca Matteo Stanca, and Alessandro Turrini (2002) 'Wage premia and skill upgrading in italy: Why didn't the hound bark?' Technical Report 3202, CEPR Working Paper

OECD (1997) 'Trade, earnings and employment: Assessing the impact of trade with emerging economies on OECD labour markets.' In Employment Outlook, ed. OECD (Paris: OECD) 
Quintieri, B., and F. C. Rosati (1995) 'Employment structure, technological change and international trade: The italian manufacturing sector in the eighties.' In Patterns of Trade, Competition and Trade Policies, ed. B. Quintieri (Avebury) pp. 133-155

Richardson, J. (1995) 'Income inequality and trade: How to think, what to conclude.' Journal of Economic Perspectives 9, 33-55

Slaughter, Matthew (1998) 'International trade and labor market outcomes: Results, outcomes, and policy options.' Economic Journal 110, 163-187 (1999) 'Globalizationa and wages: A tale of two perspectives.' The World Economy 22, 609-30

Sorce, Alberto, and Natale Fazio (1999) 'SISSIEI - the statistical information system on enterprises and institutions.' Paper presented at the International Seminar on Exchange of Technology and Knowhow, Prague, (13 - 15/10/99), ISTAT

Topel, R. (1997) 'Factor proportions and relative wages: The supply-side determinants of wage inequality.' Journal of Economic Perspectives

Wood, Adrian (1995) 'How trade hurt unskille workers.' Journal of Economic Perspectives 9, 57-80 
Table 1: Employment and wages: overall and sub-sample averages

\begin{tabular}{lcccccccc}
\hline \hline Sample & $\frac{W B_{n}}{W B}$ & $\frac{W_{n}}{W}$ & $\frac{E_{n}}{E}$ & $W_{n}$ & $W$ & $E_{n}$ & $E$ & N.Obs. \\
\hline Overall & 43.3 & 135.9 & 31.8 & 68.2 & 50.2 & 43.3 & 136.0 & 59087 \\
1989 & & & & & & & & \\
1990 & 41.7 & 135.1 & 30.2 & 55.1 & 40.8 & 41.6 & 137.8 & 8441 \\
1991 & 42.5 & 135.3 & 30.9 & 59.4 & 44.1 & 43.4 & 140.4 & 8441 \\
1992 & 43.8 & 136.2 & 32.1 & 69.9 & 51.3 & 43.6 & 135.7 & 8441 \\
1993 & 44.4 & 135.5 & 32.8 & 71.8 & 53.0 & 43.4 & 132.4 & 8441 \\
1994 & 44.5 & 135.1 & 32.9 & 75.3 & 55.8 & 43.6 & 132.2 & 8441 \\
1995 & 44.3 & 135.9 & 32.6 & 79.8 & 58.7 & 43.4 & 133.2 & 8441 \\
& & & & & & & & \\
Small & 25.8 & 128.5 & 20.1 & 51.6 & 40.2 & 4.5 & 22.2 & 7969 \\
Medium & 31.7 & 134.7 & 23.5 & 58.3 & 43.3 & 11.5 & 48.8 & 37238 \\
Large & 46.5 & 134.2 & 34.7 & 70.5 & 52.5 & 150.9 & 435.3 & 13880 \\
& & & & & & & & \\
North & 43.4 & 135.4 & 32.0 & 68.5 & 50.6 & 43.1 & 134.5 & 47438 \\
Centre & 44.1 & 136.4 & 32.4 & 68.3 & 50.1 & 48.1 & 148.7 & 9015 \\
South & 36.0 & 140.2 & 25.7 & 58.7 & 41.9 & 30.7 & 119.5 & 2634 \\
& & & & & & & & \\
High exp. & 43.1 & 135.9 & 31.8 & 67.9 & 50.0 & 49.9 & 157.1 & 29540 \\
Low exp. & 43.4 & 136.0 & 31.9 & 68.6 & 50.4 & 36.7 & 114.9 & 29547 \\
& & & & & & & & \\
High tech. & 47.6 & 134.7 & 35.3 & 68.2 & 50.6 & 55.0 & 155.8 & 29526 \\
Low tech. & 37.4 & 137.6 & 27.2 & 68.2 & 49.5 & 31.6 & 116.2 & 29561 \\
\hline Note: $\frac{W B_{n}}{W B}=$ & non-manual wage bill share; $\frac{W_{n}}{W}=$ skill premium; $\frac{E_{n}}{E}=$ skill \\
intensity; $W$ & $=$ & average wage; $W_{n}=$ non-manual wage; $E=$ employment; \\
$E_{n}=$ non-manual employment. See section 3 for sub-sample definitions. &
\end{tabular}


Table 2: Employment and wages: sub-sample averages by size

\begin{tabular}{|c|c|c|c|c|c|c|c|c|}
\hline Sample & $\frac{W B_{n}}{W B}$ & $\frac{W_{n}}{W}$ & $\frac{E_{n}}{E}$ & $W_{n}$ & $W$ & $E_{n}$ & $E$ & N.Obs. \\
\hline \multicolumn{9}{|l|}{ Small } \\
\hline High exp. & 28.9 & 126.2 & 22.9 & 51.5 & 40.8 & 5.1 & 22.4 & 3006 \\
\hline Low exp. & 23.9 & 130.0 & 18.4 & 51.8 & 39.8 & 4.1 & 22.1 & 4963 \\
\hline High tech. & 29.8 & 126.7 & 23.6 & 51.9 & 41.0 & 5.2 & 22.2 & 3497 \\
\hline Low tech. & 22.6 & 129.8 & 17.4 & 51.4 & 39.6 & 3.9 & 22.2 & 4472 \\
\hline \multicolumn{9}{|l|}{ Medium } \\
\hline High exp. & 34.0 & 133.1 & 25.5 & 58.7 & 44.1 & 13.0 & 50.8 & 18226 \\
\hline Low exp. & 29.2 & 136.1 & 21.5 & 57.7 & 42.4 & 10.1 & 46.9 & 19012 \\
\hline High tech. & 35.7 & 132.9 & 26.9 & 58.2 & 43.8 & 13.3 & 49.6 & 18336 \\
\hline Low tech. & 27.6 & 136.5 & 20.2 & 58.3 & 42.7 & 9.7 & 48.1 & 18902 \\
\hline \multicolumn{9}{|l|}{ Large } \\
\hline High exp. & 45.3 & 135.3 & 33.5 & 69.9 & 51.6 & 147.1 & 439.1 & 8308 \\
\hline Low exp. & 48.2 & 132.3 & 36.4 & 71.3 & 53.9 & 156.6 & 429.7 & 5572 \\
\hline High tech. & 50.3 & 133.6 & 37.7 & 70.2 & 52.6 & 177.0 & 469.7 & 7693 \\
\hline Low tech. & 40.8 & 135.3 & 30.2 & 71.0 & 52.5 & 118.4 & 392.5 & 6187 \\
\hline
\end{tabular}


Table 3: Wage bill share decompositions: overall and by sub-sample

\begin{tabular}{|c|c|c|c|c|c|c|c|c|}
\hline Sample & WBtot & Etot & Wtot & Ebet & Ewit & Wbet & Wwit & N.Obs. \\
\hline 1989-95 & 0.58 & 0.51 & 0.07 & -0.12 & 0.63 & 0.06 & 0.01 & 8203 \\
\hline 89-92 & 1.00 & 0.83 & 0.16 & 0.12 & 0.72 & 0.08 & 0.09 & 8205 \\
\hline 92-95 & 0.17 & 0.20 & -0.02 & -0.37 & 0.57 & 0.06 & -0.08 & 8267 \\
\hline High exp. & 0.28 & 0.22 & 0.06 & -0.11 & 0.33 & 0.04 & 0.03 & 4168 \\
\hline Low exp. & 0.30 & 0.29 & 0.01 & -0.01 & 0.30 & 0.03 & -0.02 & 4035 \\
\hline High tech. & 0.29 & 0.24 & 0.05 & -0.15 & 0.39 & 0.05 & -0.01 & 4154 \\
\hline Low tech. & 0.29 & 0.27 & 0.02 & 0.03 & 0.24 & 0.01 & 0.02 & 4049 \\
\hline Hexp-Htech & 0.14 & 0.11 & 0.03 & -0.10 & 0.21 & 0.02 & 0.01 & 2273 \\
\hline Hexp-Ltech & 0.14 & 0.11 & 0.03 & -0.01 & 0.12 & 0.01 & 0.02 & 1895 \\
\hline Lexp-Htech & 0.15 & 0.14 & 0.02 & -0.05 & 0.19 & 0.03 & -0.01 & 1881 \\
\hline Lexp-Ltech & 0.15 & 0.16 & -0.01 & 0.04 & 0.12 & -0.00 & -0.00 & 2154 \\
\hline
\end{tabular}


Table 4: Hours and hourly wages: overall and sub-sample averages

\begin{tabular}{lccccccc}
\hline \hline Sample & $\frac{\omega_{n}}{\omega}$ & $\frac{h_{n}}{h}$ & $\omega_{n}$ & $\omega$ & $h_{n}$ & $h$ & N.Obs. \\
\hline Overall & 131.5 & 103.3 & 39.6 & 30.1 & 1720.6 & 1665.2 & 59083 \\
& & & & & & & \\
1989 & 131.2 & 102.9 & 32.1 & 24.4 & 1718.7 & 1669.8 & 8441 \\
1990 & 130.4 & 103.3 & 34.8 & 26.7 & 1708.7 & 1653.4 & 8440 \\
1991 & 130.1 & 104.0 & 38.1 & 29.3 & 1714.6 & 1648.6 & 8441 \\
1992 & 131.9 & 103.3 & 40.6 & 30.8 & 1723.6 & 1668.2 & 8441 \\
1993 & 130.1 & 104.1 & 41.6 & 32.0 & 1724.1 & 1655.6 & 8439 \\
1994 & 131.4 & 102.8 & 43.8 & 33.4 & 1718.8 & 1671.6 & 8440 \\
1995 & 132.4 & 102.7 & 46.0 & 34.7 & 1736.1 & 1690.8 & 8441 \\
& & & & & & & \\
High exp. & 131.0 & 103.7 & 39.4 & 30.1 & 1723.7 & 1661.7 & 29538 \\
Low exp. & 132.3 & 102.8 & 39.9 & 30.2 & 1716.5 & 1670.1 & 29545 \\
& & & & & & & \\
High tech. & 130.5 & 103.2 & 39.9 & 30.6 & 1709.2 & 1656.8 & 29523 \\
Low tech. & 132.5 & 103.8 & 39.2 & 29.5 & 1740.5 & 1676.5 & 29560 \\
\hline \multicolumn{7}{l}{ Note: $\omega_{n}=$ non-manual hourly wage per worker; $h_{n}=$ non-manual } \\
average number of hours worked per employee (see section 5).
\end{tabular}

Table 5: Hours and hourly wages in wage bill decompositions

\begin{tabular}{lcccccccc}
\hline \hline Sample & WBtot & Ewit & Ebet & Hwit & Hbet & HWwit & HWbet & N.Obs. \\
\hline 1989-95 & 0.58 & 0.63 & -0.12 & 0.19 & -0.00 & -0.18 & 0.06 & 8203 \\
89-92 & 1.00 & 0.74 & 0.11 & 0.41 & 0.04 & -0.34 & 0.04 & 8204 \\
92-95 & 0.17 & 0.57 & -0.38 & -0.03 & -0.09 & -0.06 & 0.16 & 8267 \\
& & & & & & & & \\
High exp. & 0.28 & 0.33 & -0.11 & 0.12 & -0.01 & -0.09 & 0.05 & 4168 \\
Low exp. & 0.30 & 0.30 & -0.01 & 0.07 & 0.01 & -0.09 & 0.01 & 4035 \\
& & & & & & & & \\
High tech. & 0.29 & 0.39 & -0.15 & 0.14 & -0.00 & -0.15 & 0.06 & 4154 \\
Low tech. & 0.29 & 0.24 & 0.03 & 0.05 & 0.00 & -0.03 & 0.00 & 4049 \\
\hline $\begin{array}{l}\text { Note: } \text { W Btot }=\text { non-manual wage bill share, Ewit = Employment within, } \\
\text { Ebet = Employment between, Hwit }=\text { Hours within, Hbet = Hours between, }\end{array}$ \\
HWwit = Hourly wage within, HWbet = Hourly wage between.
\end{tabular}


Table 6: Determinants of wage bill components

\begin{tabular}{|c|c|c|c|c|c|}
\hline Dep. Var. & $\Delta l S$ & $I C I$ & $R D S$ & $R^{2}$ & N.Obs. \\
\hline WBwit & $\begin{array}{c}-0.02 \\
(-1.24)\end{array}$ & $\begin{array}{c}0.07 \\
(2.09)\end{array}$ & $\begin{array}{c}0.09 \\
(1.29)\end{array}$ & 0.04 & 7377 \\
\hline$W$ Bbet & $\begin{array}{c}0.72 \\
(9.91)\end{array}$ & $\begin{array}{l}-0.20 \\
(-1.37)\end{array}$ & $\begin{array}{c}0.12 \\
(0.46)\end{array}$ & 0.04 & 7377 \\
\hline Ewit & $\begin{array}{c}-0.04 \\
(-1.69)\end{array}$ & $\begin{array}{c}0.08 \\
(2.04)\end{array}$ & $\begin{array}{c}0.12 \\
(1.34)\end{array}$ & 0.03 & 7377 \\
\hline Ebet & $\begin{array}{c}0.62 \\
(10.07)\end{array}$ & $\begin{array}{c}-0.19 \\
(-1.50)\end{array}$ & $\begin{array}{c}0.23 \\
(0.92)\end{array}$ & 0.04 & 7377 \\
\hline Wwit & $\begin{array}{c}0.01 \\
(0.94)\end{array}$ & $\begin{array}{c}-0.01 \\
(-0.79)\end{array}$ & $\begin{array}{c}-0.03 \\
(-0.71)\end{array}$ & 0.01 & 7377 \\
\hline Wbet & $\begin{array}{c}0.10 \\
(3.98)\end{array}$ & $\begin{array}{c}-0.01 \\
(-0.35)\end{array}$ & $\begin{array}{c}-0.11 \\
(-0.69)\end{array}$ & 0.02 & 7377 \\
\hline Hwit & $\begin{array}{c}-0.02 \\
(-1.87)\end{array}$ & $\begin{array}{c}0.02 \\
(0.64)\end{array}$ & $\begin{array}{c}0.34 \\
(3.78)\end{array}$ & 0.00 & 7377 \\
\hline Hbet & $\begin{array}{c}0.11 \\
(3.52)\end{array}$ & $\begin{array}{c}-0.07 \\
(-1.23)\end{array}$ & $\begin{array}{c}-0.03 \\
(-0.17)\end{array}$ & 0.01 & 7377 \\
\hline$H W w i t$ & $\begin{array}{c}0.03 \\
(2.22)\end{array}$ & $\begin{array}{c}-0.03 \\
(-1.02)\end{array}$ & $\begin{array}{c}-0.37 \\
(-3.87)\end{array}$ & 0.01 & 7377 \\
\hline HWbet & $\begin{array}{c}-0.01 \\
(-0.50)\end{array}$ & $\begin{array}{c}0.06 \\
(1.41)\end{array}$ & $\begin{array}{c}-0.07 \\
(-1.43)\end{array}$ & 0.00 & 7377 \\
\hline
\end{tabular}

Note: t-statistics in parentheses. All specifications include size, geography and industry sector dummies, as defined in section 3. Legend: $\Delta l S=$ growth rate of sales; $I C I=$ Computer share of total investment; $R D S=R \& D /$ sales. 
Table 7: Determinants of within firm skill upgrading

\begin{tabular}{lccccccc}
\hline \hline Equation & $\alpha$ & $\Delta l W n m$ & $\Delta l K Y$ & $I C I$ & $R D S$ & $R^{2}$ & N.Obs. \\
\hline$(1)$ & 0.48 & 0.11 & 0.34 & & & 0.23 & 8136 \\
& $(31.21)$ & $(32.51)$ & $(2.10)$ & & & & \\
$(2)$ & 0.43 & 0.11 & 0.36 & 0.56 & & 0.24 & 7742 \\
& $(24.84)$ & $(32.32)$ & $(2.22)$ & $(5.91)$ & & & \\
$(3)$ & 0.49 & 0.11 & 0.40 & & 0.52 & 0.24 & 7684 \\
& $(30.87)$ & $(31.89)$ & $(2.39)$ & & $(3.36)$ & & \\
$(4)$ & 0.44 & 0.11 & 0.43 & 0.58 & 0.51 & 0.25 & 7321 \\
& $(24.53)$ & $(31.82)$ & $(2.52)$ & $(5.94)$ & $(3.62)$ & & \\
\hline
\end{tabular}

Note: t-statistics in parentheses. Dependent variable: $\Delta w b s h=$ change in log relative wage bill; $\Delta l W n m=$ change in log relative annual wage; $\Delta l K Y=$ change in log capital output ratio; $I C I=$ Computer share of total investment; $R D S=R \& D /$ sales.

Table 8: Determinants of within firm skill upgrading (hourly wages)

\begin{tabular}{lccccccc}
\hline \hline Equation & $\alpha$ & $\Delta l H W n m$ & $\Delta l K Y$ & $I C I$ & $R D S$ & $R^{2}$ & N.Obs. \\
\hline$(1)$ & 0.52 & 0.07 & 0.46 & & & 0.14 & 8135 \\
& $(32.14)$ & $(20.48)$ & $(2.71)$ & & & & \\
$(2)$ & 0.47 & 0.07 & 0.46 & 0.59 & & 0.14 & 7741 \\
& $(25.67)$ & $(19.86)$ & $(2.66)$ & $(5.76)$ & & & \\
$(3)$ & 0.53 & 0.07 & 0.50 & & 0.97 & 0.14 & 7684 \\
& $(31.53)$ & $(19.98)$ & $(2.82)$ & & $(5.46)$ & & \\
$(4)$ & 0.48 & 0.07 & 0.50 & 0.63 & 0.97 & 0.15 & 7321 \\
& $(25.03)$ & $(19.50)$ & $(2.77)$ & $(5.92)$ & $(5.57)$ & & \\
\hline
\end{tabular}

Note: t-statistics in parentheses. Dependent variable: $\Delta w b s h=$ change in log relative wage bill; $\Delta l H W n m=$ change in log relative hourly wage; $\Delta l K Y=$ change in log capital output ratio; $I C I=$ Computer share of total investment; $R D S=R \& D /$ sales. 